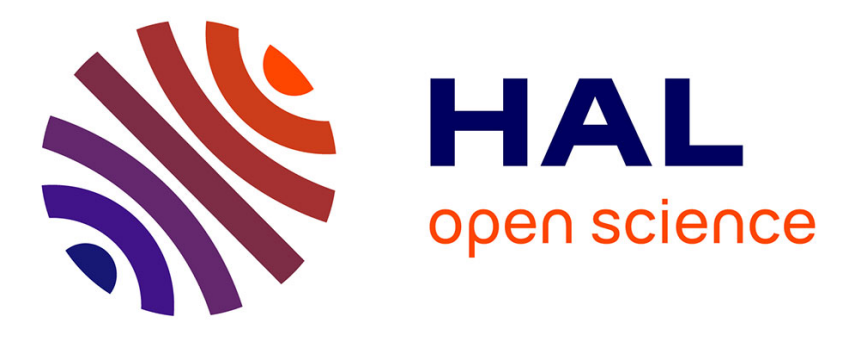

\title{
Plasmin on adherent cells: from microvesiculation to apoptosis
}

\author{
Loïc Doeuvre, Laurent Plawinski, Didier Goux, Denis Vivien, Eduardo \\ Anglés-Cano
}

\section{- To cite this version:}

Loïc Doeuvre, Laurent Plawinski, Didier Goux, Denis Vivien, Eduardo Anglés-Cano. Plasmin on adherent cells: from microvesiculation to apoptosis. Biochemical Journal, 2010, 432 (2), pp.365-373. 10.1042/BJ20100561 . hal-00535582

\section{HAL Id: hal-00535582 \\ https://hal.science/hal-00535582}

Submitted on 12 Nov 2010

HAL is a multi-disciplinary open access archive for the deposit and dissemination of scientific research documents, whether they are published or not. The documents may come from teaching and research institutions in France or abroad, or from public or private research centers.
L'archive ouverte pluridisciplinaire HAL, est destinée au dépôt et à la diffusion de documents scientifiques de niveau recherche, publiés ou non, émanant des établissements d'enseignement et de recherche français ou étrangers, des laboratoires publics ou privés. 


\section{Plasmin on adherent cells: from microvesiculation to apoptosis}

\section{Loïc Doeuvre* ${ }^{*}$, Laurent Plawinski ${ }^{*}$, , Didier Goux ${ }^{*}$, Denis Vivien* and Eduardo Anglés-Cano*}

* Inserm U919, Caen, France

†Université de Caen Basse-Normandie, Caen, France

$¥$ CMABIO, Université de Caen, IFR 146, Caen, France

${ }^{\S}$ CNRS UMR6232, Caen, France

Author for correspondence:

Eduardo Anglés-Cano M.D., Sc.D. (Eduardo.Angles-Cano@inserm.fr)

Inserm U919 Serine Proteases and Pathophysiology of the neurovascular Unit GIP Cyceron/Bd Henri Becquerel

14074, Caen, France

Tel: 0033231470164

Fax: 0033231470222

Alternate Email: angles@cyceron.fr

Heading title: Cell activation by plasmin: microvesiculation, apoptosis 


\title{
SYNOPSIS
}

Cell activation by stressors is characterised by a sequence of detectable phenotypic cell changes. A given stimulus, depending on its strength, induces modifications in the activity of membrane phospholipid transporters and calpains, which lead to phosphatidylserine exposure, membrane blebbing and the release of microparticles (nanoscale membrane vesicles). This vesiculation could be considered as a warning signal that may be followed, if the stimulus is maintained, by cell detachment-induced apoptosis.

In this study, plasminogen incubated with adherent cells is converted into plasmin by constitutively expressed tPA or uPA. Plasmin formed on the cell membrane then induces a unique response characterized by membrane blebbing and vesiculation. Hitherto unknown for plasmin, these membrane changes are similar to those induced by thrombin on platelets. If plasmin formation persists, matrix proteins are then degraded, cells lose their attachments and enter the apoptotic process, characterized by DNA fragmentation and specific ultrastructural features.

Since other proteolytic or inflammatory stimuli may evoke similar responses in different types of adherent cells, the proposed experimental procedure can be used to distinguish activated adherent cells from cells entering the apoptotic process. Such a distinction is crucial for evaluating effects of mediators, inhibitors and potential therapeutic agents.

Key words: Plasminogen, membrane blebbing, microparticles, apoptosis, electron microscopy

\author{
Abbreviations used: \\ Microparticles: MPs \\ Urokinase type plasminogen activator: uPA \\ Tissue-type plasminogen activator: tPA \\ Extracellular matrix: ECM \\ $\varepsilon$-aminocaproic acid: $\varepsilon$-ACA \\ Tetrazolium salt 3-[4,5-dimethylthiazol-2-yl]-2,5-diphenyl tetrazolium bromide: MTT \\ Carboxypeptidase B: $\mathrm{CpB}$ \\ 4', 6-diamino-2-phenylindole: DAPI \\ Terminal Deoxynucleotidyltransferase-mediated dUTP Nick End Labeling: TUNEL
}




\section{INTRODUCTION}

Cell response to a number of stressors and inflammatory mediators is key to maintenance of tissue homeostasis. The initial response of activated cells may evolve to apoptosis depending on the type and strength of stimuli [1]. Early manifestations of this cell activation process are the formation of membrane blebs and the shedding of nanoscale membrane fragments known and designated hereafter as microparticles (MPs, 0.1 to $1 \mu \mathrm{m}$ ) [2]. Since the first discovery of MPs in platelet-free plasma [3, 4], the most well known cellular MPs are those of platelet, leukocyte, erythrocyte and endothelial cell origin found in circulating blood [5]. A number of studies have demonstrated that stimulation of these cells is followed by the characteristic features of cell activation: increased levels of cytoplasmic calcium associated to exposure of phosphatidylserine and activation of calpains (EC 3.4.22) [6]. The increase in intracellular calcium induces a disordered state in the concerted activity of membrane transporter proteins (flippases, floppases and scramblases) that maintain the membrane phospholipid asymmetry of quiescent cells $[7,8]$. As a result, procoagulant phosphatidylserine is translocated from the inner leaflet to the external leaflet of the membrane. The activated calpains cleave cytoskeleton filaments and thereby facilitate membrane blebbing and shedding of MPs. In addition to their procoagulant activity, MPs carry at their surface identity antigens that characterize their cellular origin. Since they also convey proteolytic glycoproteins, growth factor or inflammatory mediators, they are currently considered as a storage pool of bioactive effectors [9]. Proteolytic mediators that have been identified include the plasminogen activation system and the matrix metalloproteases (EC 3.4.24) [10-13].

The plasminogen activation system is involved in fibrinolysis and in pericellular proteolysis [14]. Finely regulated, cellular plasminogen activation plays an essential role in extracellular matrix (ECM) remodelling [1], cell migration [15] and survival [16]. The central mechanism is the transformation of plasminogen into plasmin (EC 3.4.21.7), the active enzyme, at cell membranes, the ECM or the surface of fibrin, by the urokinase- or the tissue-typeplasminogen activator, uPA (EC 3.4.21.73) or tPA (EC 3.4.21.68), respectively. MPs function as a catalytic surface for plasmin formation by providing both plasminogen activators and plasminogen binding sites [10]. Interestingly, the uPA system of MPs also participates in the formation of plasmin at the surface of platelets, fibrin or the ECM via a fibrinolytic/proteolytic cross-talk mechanism recently described [17]. Thrombin (EC 3.4.21.6), another serine protease, is known to induce the release of MPs from platelets, but the plasmin potential to induce vesiculation is not known as yet.

Beyond activation-dependant release of MPs, the survival of cells within structural-functional units involving tissue specific components and the microvasculature (e.g. neurovascular unit, glomerulus and pulmonary alveolus), depends on dynamic cell-matrix interactions that ensure their adhesion to the substratum and tissue cohesion. Thus, in the absence of any ECM interaction, human endothelial cells rapidly enter apoptosis [18]. Accordingly, excessive proteolysis of the ECM by cells that express a plasminogen activator system results in loss of cell anchorage and apoptosis [19], a phenomenon that may be of relevance in pathological situations in vivo [20]. Discerning the steps of this cell activation and apoptosis process is therefore crucial for evaluating effects of mediators, inhibitors and potential therapeutic agents.

We unveil in this report that plasmin provokes the release of cell-derived MPs and propose a sequence of events initiated by plasminogen activation on adherent cells and spanning from early blebbing and vesiculation to subsequent cell detachment and apoptosis/survival. Because other proteolytic or inflammatory stimuli may evoke similar responses in different types of adherent cells, the proposed mechanistic procedure can be used to distinguish activated adherent cells from cells entering the apoptotic process. 


\section{EXPERIMENTAL}

\section{Reagents and proteins}

Human Glu-plasminogen used in this study was purified and characterized as described [21] and was over $99 \%$ pure as assessed by SDS-PAGE and by amino-terminal sequence analysis. Plasmin was prepared by activation of Glu-plasminogen with immobilized uPA according to Wiman and Wallen [22] with modifications. Rabbit anti-mouse laminin polyclonal antibody was kindly provided by H. P. Erickson (Duke University Medical Center, Durham, NC). The peroxidase-labelled monoclonal antibody directed against plasminogen kringle 1 (CPL15-PO) was prepared as described [19]. Active-site blocked plasmin (D-Val-Phe-Lyschloromethylketone, dihydrochloride, Pn-VFK) was prepared as described previously [16]. The plasminogen activators uPA (140 $000 \mathrm{iu} / \mathrm{mg}$ ) and tPA (578 $000 \mathrm{iu} / \mathrm{mg}$ ) both over 99\% single-chain form were obtained from Biopool AB (Umea, Sweden) and Abbot (Chicago, Il, USA), respectively. Aprotinin was a kind gift from Bayer HealthCare AG (Leverkusen, Germany). Glutamine, foetal calf serum and DMEM-Ham's F-12 medium were obtained from Invitrogen (Carlsbad, CA, USA). The chromogenic substrate selective for plasmin (methylmalonyl)-hydroxyprolylarginine-para-nitroaniline (CBS0065) was from Stago (Asnieres, France). The plasmin inhibitor VFK was from calbiochem (Darmstadt, Germany). The lysine analogue $\varepsilon$-aminocaproic acid ( $\varepsilon$-ACA), the tetrazolium salt 3-[4,5dimethylthiazol-2-yl]-2,5-diphenyl tetrazolium bromide (MTT), dimethyl sulfoxide (DMSO), carboxypeptidase B (CpB, porcine pancreas), 4', 6-diamino-2-phenylindole (DAPI) were from Sigma (St-Louis, MO, USA). The terminal Deoxynucleotidyltransferase-mediated dUTP Nick End Labeling (TUNEL) was from Roche Applied Science (Neuilly sur Seine, France).

\section{Identification of cell plasminogen activators}

Chinese hamster ovary cells (CHO-K1 cells, American Type Culture Collection CCL-61, fibroblast phenotype), human embryonic kidney cells (HEK-293, [23]) and human microvascular endothelial cells (HMEC-1, [24]) were used as prototype adherent cells. Cells were grown in a $37^{\circ} \mathrm{C}$ humidified atmosphere of $5 \% \mathrm{CO}_{2}$ using DMEM-Ham's F-12 medium (CHO-K1 cells) or RPMI medium (HEK-293 and HMEC-1 cells) supplemented with $2 \mathrm{mM}$ L-glutamine and 10\% foetal calf serum. Cells were then seeded in 96 or 24 wells plates, depending on experiments. Fibrin autography following SDS-PAGE was performed as described previously [25]. Briefly, cells were lysed in $100 \mathrm{mM}$ Tris- $\mathrm{HCl}$ buffer, $\mathrm{pH} 8.1$, containing $1 \%$ Triton X-100. Proteins in cell lysates $(100 \mu \mathrm{g})$ and reference proteins $(10 \mu \mathrm{L}$ of tPA 1 pmol, uPA $0.2 \mathrm{pmol}$ and plasmin 100 pmol) were electrophoresed in a $8 \%$ polyacrylamide gel under non-reducing conditions. SDS was then exchanged with $2.5 \%$ Triton X-100. After washing-off excess Triton X-100 with distilled water, the gel was carefully overlaid on a $1 \%$ agarose gel containing $1 \mathrm{mg} / \mathrm{mL}$ of bovine fibrinogen, $100 \mathrm{nM}$ plasminogen and $0.2 \mathrm{NIH}$ unit/mL of bovine thrombin. Zymograms were allowed to develop at $37^{\circ} \mathrm{C}$ during $12 \mathrm{~h}$ and photographed at regular intervals using dark-ground illumination. Active proteins in cell lysates were identified by reference to the migration of known markers (uPA, tPA, plasmin). To verify the activator identity, cell lysates were incubated with a polyclonal antibody directed against tPA or UPA and their residual activity detected by radial diffusion on fibrin-agarose gels.

\section{Cell activation by plasmin}

Cells were incubated with Glu-plasminogen $(1 \mu \mathrm{M})$ at $37^{\circ} \mathrm{C}$, in the presence of $0.75 \mathrm{mM}$ of CBS0065, a plasmin selective chromogenic substrate. In parallel experiments, the effect of various inhibitors ( $\varepsilon$-ACA, a lysine analogue that blocks plasminogen binding to cells; $\mathrm{CpB}$, an exopeptidase that cleaves C-ter Lys residues on cells; aprotinin, a serine-protease inhibitor 
with restricted specificity) on plasminogen activation $(1 \mu \mathrm{M})$ was determined in the presence of $0.75 \mathrm{mM}$ of CBS0065.

Kinetics of plasmin formation was followed by measuring the release of $p$-nitroaniline from the chromogenic substrate, detected as a change in absorbance $\left(\Delta \mathrm{A}_{405 \mathrm{~nm}} / \mathrm{min}\right)$, using a multiwell plate reader (Biotek ELx808) thermostated at $37{ }^{\circ} \mathrm{C}$. Rates of plasmin formation were calculated from slopes of $\mathrm{A}_{405 \mathrm{~nm}}$ versus time. Initial rates were computer-calculated at the inflexion point of the curve by non-linear regression analysis, and were fitted to the Michaelis-Menten equation considering a non-specific component $(\mathrm{k}[\mathrm{Pg}])$ proportional to plasminogen concentration $([\mathrm{Pg}])$.

$$
\frac{V_{\text {max }}[P g]}{K m+[P g]}+k[P g]
$$

\section{Detection of cell blebbing and release of microparticles by activated cells}

Supernatants of activated cells, collected at different time points during plasminogen activation, were supplemented with $2 \%$ glutaraldehyde before cytospinning detached cells at $800 \mathrm{~g}$ for 5 min (cytospin ${ }^{\circledR}$ Thermo Fisher Scientific, USA) on small Thermanox ${ }^{\circledR}$ (NUNC, USA) coverslips. These cover slips support cells all along the preparation until the end of polymerization and embedding of the resin for electron microscopy. Rapidly after cytospinning, the Thermanox coverslips were transferred into a cap containing phosphate buffer. Cells were then rinsed 3 times in phosphate buffer $(0.1 \mathrm{M}, \mathrm{pH} 7.4)$ before and after post-fixation with $0.5 \%$ osmium tetroxide, dehydrated through a graded ethanol series $(70 \%$ $2 \mathrm{x}, 95 \% 3 \mathrm{x}, 100 \% 4 \mathrm{x})$ and finally embedded in epon resin. After polymerization, the coverslips were removed and ultrathin sections were stained with $2 \%$ uranyl acetate and lead citrate. All observations were performed with a JEOL 1011 transmission electron microscope. Images were acquired with a megaview III camera (SIS).

\section{Microparticle isolation}

MPs were isolated from culture medium conditioned by subconfluent adherent cells stimulated for $24 \mathrm{~h}$ with $1 \mu \mathrm{M}$ plasminogen. Culture supernatants were collected and cleared from detached cells or large cell fragments by centrifugation at $1500 \mathrm{~g}$ for $15 \mathrm{~min}$. The supernatants were then centrifuged at $20000 \mathrm{~g}$ for $90 \mathrm{~min}$ at $4^{\circ} \mathrm{C}$. Pelleted MPs were washed twice using the same conditions and were suspended in $0.1 \mathrm{M}$ phosphate-buffer.

\section{Determination of cell survival by the MTT method}

At indicated time intervals during plasminogen activation, the conditioned medium was carefully removed from a 96-well plate without disturbing the cell monolayer and was replaced with $100 \mu \mathrm{L}$ of $0.5 \mathrm{mg} / \mathrm{mL}$ MTT. The tetrazolium salt was transformed into formazan by the mitochondrial succinate deshydrogenase of living cells. After $1 \mathrm{~h}$ at $37^{\circ} \mathrm{C}$, excess MTT was removed and the formed crystals of formazan were dissolved in $100 \mu \mathrm{L}$ of DMSO and colorimetrically detected at $\mathrm{A}_{550 \mathrm{~nm}}$. Absorbance readings are proportional to the number of living cells. The results are expressed as a percentage compared to control cells.

\section{TUNEL and DAPI staining}

Cells in supernatants collected at different time intervals after plasminogen activation were cytospun onto glass slides. TUNEL was used to visualize DNA fragmentation. The cells were then counter-stained with DAPI to visualize all nuclei. After washing, the slides were mounted and observed under an epifluorescence microscope. The TUNEL index was calculated as the percentage of TUNEL-positive nuclei relative to total DAPI-stained nuclei. 


\section{Western Blot}

Plasmin-activated cells or MPs were lysed in $100 \mathrm{mM}$ Tris-HCl buffer, $\mathrm{pH} 8.1$, containing 1\% Triton X-100. Proteins in lysates $(10 \mu \mathrm{g})$ were electrophoresed in an $8 \%$ polyacrylamide gel under reducing conditions. Proteins were transferred to PVDF membranes and revealed with primary specific antibodies (a sheep antibody directed against uPA, a rabbit antibody directed against laminin and a peroxidase-labelled monoclonal antibody directed against plasminogen kringle 1) at proper concentrations and HRP-coupled secondary antibodies when indicated.

\section{Statistical analyses}

Data are expressed as mean \pm standard error of the mean (SEM). The statistics were performed using nonparametric tests of Kruskall Wallis and of Mann Whitney (MYSTAT12 software). Statistical significance was set at $\mathrm{p}<0.05$.

\section{RESULTS-DISCUSSION}

Cell membrane stability and functioning depend on coupling of transbilayer phospholipid asymmetry to the cytoskeleton. In adherent cells, stability is further enhanced by coupling of integral membrane protein receptors (integrins) to ECM glycoproteins such as fibronectin, laminin, collagen, thrombospondins and tenascins that act as a scaffold surface for cell adhesion. They function as a mediator of cytoskeleton reorganization leading to formation of focal adhesions and intracellular signalling [26, 27] that direct cell growth, morphology, migration and anchorage-dependent survival [28]. Disruption of the transbilayer phospholipid asymmetry, a feature of cell activation, or of ECM-integrin interactions by proteolysis may have consequences on membrane cytoskeleton reorganization and on cell adhesion during tissue remodeling or in pathological proteolysis $[20,29,30]$. We therefore explored the possibility that plasmin formation on cells may induce these phenotypic cell changes. We provide here the first demonstration that plasmin generated at the surface of adherent cells induces an early response characterized by membrane blebbing and vesiculation, i.e., release of MPs. In addition, we show that plasmin proteolyses ECM proteins and thereby disrupt interactions with cells that result in phenotypic changes characteristic of cell detachment and apoptosis. Thus, in agreement with previous reports [8,31], localized decoupling of the cytoskeleton to the membrane results in formation of a bleb exposing phosphatidylserine [8] and loss of anchoring to the matrix results in reorganization of focal adhesions and cell detachment [31]. Membrane blebs, MPs and cells activated or entering apoptosis express phosphatidylserine at the outer leaflet [6]. Fluorescent annexin A5 has been used to detect the exposed phosphatidylserine by flow cytometric analysis [32]. Since MPs may contaminate cell preparations [33], the annexin A5 binding assay cannot discriminate amongst cells or MPs expressing phosphatidylserine [34]. To better identify early morphological changes (membrane blebbing and vesiculation) before anchorage-depending survival of cells is compromised, we first determined the ability of cells to express plasminogen activators and then monitored plasmin formation and its effects on cell blebbing and survival.

We demonstrate that CHO-K1 and HEK-293 cells express active tPA whereas HMEC-1 cells express UPA as indicated by the position of a fibrinolytic band similar to the migration of purified UPA or tPA detected by fibrin zymography (Fig. 1A, upper panel). Confirmation was obtained by inhibition of the fibrinolytic activity with specific antibodies as detected by radial diffusion on fibrin-agarose gels (Fig. 1A, lower panel). Unrelated antibodies had no effect on plasminogen activation (Fig. 1A, lower panel). Kinetics of plasmin formation (Fig. 1B) indicated that plasminogen incubated with cells were assembled at their surface and transformed into plasmin in a time-, lysine- and dose-dependent manner until saturation (Fig.1C). Kinetic parameters were determined by fitting data to the Michaelis-Menten 
equation including a non-specific component of uptake (Vmax $[\mathrm{Pg}] /(\mathrm{Km}+[\mathrm{Pg}]))+\mathrm{k}[\mathrm{Pg}])$; Table 1). The calculated $\mathrm{Km}$ value is comparable to values obtained for tPA expressed by other cell types including endothelial cells [35] and neurons [16]. It is also comparable to values determined for the activation of plasminogen by tPA on fibrin (40 to $160 \mathrm{nM}$ ) [36, 37], suggesting that the cell surface provides a similar plasminogen activation enhancement. Lysine-dependant specific plasminogen binding was indicated by inhibition of plasmin formation both with the lysine analogue $\varepsilon$-ACA that blocks the LBS of plasminogen, and with $\mathrm{CpB}$ that cleaves $\mathrm{C}$-ter lysine residues from the cell surface. The activity of plasmin formed in situ was efficiently inhibited by aprotinin (Fig. 1D).

Since thrombin, a serine protease like plasmin, induces membrane blebbing and platelet vesiculation, we explored the possibility that plasmin may induce a similar response on adherent cells. Membrane blebbing is a short-lived phenomenon observed at the very initial phase of cell stimulation that can only be visualized by electron microscopy. For that purpose, the early response of cells to plasmin formation was interrupted by glutaraldehyde fixation, thus allowing capture of multiple blebbing of the membrane and formation of numerous MPs that were about to be released from cells (Fig. 2). A small number of MPs could be detected in control culture conditions (Fig. 2A, Table 1). After incubation of cells with plasminogen, the number of MPs detected in the culture medium was dramatically increased in all adherent cell types (Fig 2A). These MPs are around $300 \mathrm{~nm}$ in size and contain substructures having an electron density similar to that of cell cytoplasm, which are surrounded by a well-defined membrane (Fig 2B, C, D). This phenomenon was dependent on the activity of plasmin as indicated by its prevention in the presence of aprotinin (data not shown). Since plasmin was the only aprotinin-sensitive serine protease present in the culture supernatant (Fig. 1B), these results indicate that membrane blebbing is one of the early responses of cells to plasmin. MPs, that are released, carry the plasminogen activator of their parental cell (e.g. uPA for HMEC-1, Fig 3A) and plasmin(ogen) bound at the membrane (Fig 3B). These results confirm that MPs could be considered as potential messengers of proteolytic activity $[9,10]$.

As indicated above, the first and immediate consequence of cellular stimulation by plasmin is membrane blebbing followed by the release of MPs. The continuous formation of plasmin has other consequences on cell phenotype and behaviour, which are related to the proteolytic activity of plasmin on the substratum. Active plasmin proteolyses and degrades components of the ECM including laminin (Fig. 3C) and fibronectin [38]. In the absence of a substratum for anchorage, the cells became round (Fig. 4A) and gradually detached from their support as shown by the amount of residual living cells (MTT assay, Fig. 4B). After $48 \mathrm{~h}$ of incubation with plasminogen, the detached CHO-K1 cells entered the apoptotic process as suggested by DNA fragmentation observable by TUNEL (Fig. 4C, D).

Electron microscopy allowed detailed observation of cell morphology and characteristic apoptotic changes (Fig. 5). In control cells, the nucleus membrane is clearly delimitated and the characteristics of normal cytoplasm are maintained including endoplasmic reticulum and mitochondria with their internal crests (Lower panel, Fig. 5A). In plasminogen-treated cells (Fig. 5B; $48 \mathrm{~h}$ ), the nucleus shows chromatin condensation, the cytoplasm is disorganized, contains lysis vesicles and mitochondria became electron dense (Lower panel, Fig 5B). After $72 \mathrm{~h}$ of stimulation, consequences of plasmin formation are dramatic: higher condensation and fragmentation of the chromatin (Fig. 5C).

To investigate the relation between plasmin formation and cell detachment, we used activesite blocked plasmin, Pn-VFK (Fig. 6A). Pn-VFK is unable to develop a proteolytic activity 
on ECM components, e.g. laminin (Fig. 3C). In the absence of ECM degradation, cells do not detach from their support and remain viable (Fig. 6B).

Altogether, these data indicate that upon plasmin formation, the proteolytic activity of this enzyme induces (1) at the cell level, membrane blebbing and vesiculation and (2) on matrix proteins, cell detachment-induced apoptosis.

Conditioned medium from cell culture experiments and animal or human biological fluids (e.g. urine) or exudates (e.g. ascites, cyst fluid, and pleural effusion) contain detached cells that can be cytospun and processed for visualization of structural and morphological changes (Fig. 7). This procedure allows identification of the initial state of cell activation before irreversible cell damage occurs, and further explores a more advanced state of cell injury characterized by nuclear and cytoplasmic abnormalities typical of apoptosis.

The advantage of the proposed procedure is that early morphological changes (membrane blebbing and vesiculation) can be easily identified before anchorage-dependent survival of cells is compromised [19, 32, 39-42]. In the absence of other morphological or structural modifications, these initial membrane changes indicate a reversible response to stimulation by stressors and can be used as indicators of cell stimulation/suffering. Another advantage is that, from the same culture supernatant or biological fluid, it could be possible to isolate (Fig. 2) and to analyze MPs (Fig. 3A, B).

Finally, in vivo proteolytic-dependant degradation of ECM and apoptosis [43-45] may also be studied. In the case of human pathologies or animal experiments this mechanistic procedure has potential application for diagnostic purposes and in the follow up of disease progression and treatment.

In conclusion, we show in this report that plasmin formed at the surface of adherent cells induces two types of response (Fig. 7): (1) membrane blebbing and vesiculation (gray arrow)the early response of adherent cells to proteolytic activation and (2) a delayed response characterized by cell detachment and apoptosis (black arrow). Investigation and analysis of this succession of events may help to identify the outcome of adherent cells in response to insults that may potentially shift from minimal structural changes (membrane blebbing and vesiculation) to apoptosis. This sequence may be operative in inflammatory processes like atherosclerosis [20] and in adherent cells derived from the central nervous system [16].

\section{ACKNOWLEDGEMENTS}

We thank Dr. Alan Young and Dr. Mary Osborne-Pellegrin for proofreading and editing the manuscript. Acces to cytospin facilites was a courtesy of Dr. Laurent Poulain.

\section{Founding}

These studies were supported by funds from the Inserm (Institut National de la Santé et de la Recherche Médicale) and the Lower-Normandy Regional Council. EAC, LP and LD are members of the European Community's Seventh Framework Programme (FP7/2007-2013) under grant agreement [201024]. LD is a recipient of a PhD fellowship from the Education and Research French Ministry.

Disclosure statement: the authors declare no competing financial interests.

\section{Authorship}

LD performed research, analyzed data and wrote the manuscript. LP provided experimental support and participated in manuscript drafting. DG contributed electron microscopy support. DV director of the research unit secured funding. EAC designed the research, analyzed data and wrote the manuscript. 


\section{REFERENCES}

1 Garcia-Touchard, A., Henry, T. D., Sangiorgi, G., Spagnoli, L. G., Mauriello, A., Conover, C. and Schwartz, R. S. (2005) Extracellular proteases in atherosclerosis and restenosis. Arterioscler Thromb Vasc Biol. 25, 1119-1127

2 Freyssinet, J. M. (2003) Cellular microparticles: what are they bad or good for? J Thromb Haemost. 1, 1655-1662

3 Chargaff, E. and West, R. (1946) The biological significance of the thromboplastic protein of blood. J Biol Chem. 166, 189-197

4 Wolf, P. (1967) The nature and significance of platelet products in human plasma. Br J Haematol. 13, 269-288

5 Morel, O., Toti, F., Hugel, B., Bakouboula, B., Camoin-Jau, L., Dignat-George, F. and Freyssinet, J. M. (2006) Procoagulant microparticles: disrupting the vascular homeostasis equation? Arterioscler Thromb Vasc Biol. 26, 2594-2604

6 Pasquet, J. M., Dachary-Prigent, J. and Nurden, A. T. (1996) Calcium influx is a determining factor of calpain activation and microparticle formation in platelets. Eur $\mathrm{J}$ Biochem. 239, 647-654

7 Bevers, E. M., Comfurius, P., Dekkers, D. W. and Zwaal, R. F. (1999) Lipid translocation across the plasma membrane of mammalian cells. Biochim Biophys Acta. 1439, 317-330

8 Daleke, D. L. (2003) Regulation of transbilayer plasma membrane phospholipid asymmetry. J Lipid Res. 44, 233-242

9 Morel, O., Toti, F., Hugel, B. and Freyssinet, J. M. (2004) Cellular microparticles: a disseminated storage pool of bioactive vascular effectors. Curr Opin Hematol. 11, 156164

10 Lacroix, R., Sabatier, F., Mialhe, A., Basire, A., Pannell, R., Borghi, H., Robert, S., Lamy, E., Plawinski, L., Camoin-Jau, L., Gurewich, V., Angles-Cano, E. and DignatGeorge, F. (2007) Activation of plasminogen into plasmin at the surface of endothelial microparticles: a mechanism that modulates angiogenic properties of endothelial progenitor cells in vitro. Blood. 110, 2432-2439

11 Dolo, V., D'Ascenzo, S., Violini, S., Pompucci, L., Festuccia, C., Ginestra, A., Vittorelli, M. L., Canevari, S. and Pavan, A. (1999) Matrix-degrading proteinases are shed in membrane vesicles by ovarian cancer cells in vivo and in vitro. Clin Exp Metastasis. 17, $131-140$

12 Taraboletti, G., D'Ascenzo, S., Borsotti, P., Giavazzi, R., Pavan, A. and Dolo, V. (2002) Shedding of the matrix metalloproteinases MMP-2, MMP-9, and MT1-MMP as membrane vesicle-associated components by endothelial cells. Am J Pathol. 160, 673680

13 Canault, M., Leroyer, A. S., Peiretti, F., Leseche, G., Tedgui, A., Bonardo, B., Alessi, M. C., Boulanger, C. M. and Nalbone, G. (2007) Microparticles of human atherosclerotic plaques enhance the shedding of the tumor necrosis factor-alpha converting enzyme/ADAM17 substrates, tumor necrosis factor and tumor necrosis factor receptor-1. Am J Pathol. 171, 1713-1723

14 Lijnen, H. R. (2001) Elements of the fibrinolytic system. Ann N Y Acad Sci. 936, 226236

15 Plow, E. F. and Hoover-Plow, J. (2004) The functions of plasminogen in cardiovascular disease. Trends Cardiovasc Med. 14, 180-186

16 Ho-Tin-Noe, B., Enslen, H., Doeuvre, L., Corsi, J. M., Lijnen, H. R. and Angles-Cano, E. (2009) Role of plasminogen activation in neuronal organization and survival. Mol Cell Neurosci. 42, 288-295 
17 Dejouvencel, T., Doeuvre, L., Lacroix, R., Plawinski, L., Dignat-Georges, F., Lijnen, H. R. and Angles-Cano, E. (2009) Fibrinolytic cross-talk: a new mechanism for plasmin formation. Blood

18 Meredith, J. E., Jr., Fazeli, B. and Schwartz, M. A. (1993) The extracellular matrix as a cell survival factor. Mol Biol Cell. 4, 953-961

19 Meilhac, O., Ho-Tin-Noe, B., Houard, X., Philippe, M., Michel, J. B. and Angles-Cano, E. (2003) Pericellular plasmin induces smooth muscle cell anoikis. Faseb J. 17, 13011303

20 Rossignol, P., Luttun, A., Martin-Ventura, J. L., Lupu, F., Carmeliet, P., Collen, D., Angles-Cano, E. and Lijnen, H. R. (2006) Plasminogen activation: a mediator of vascular smooth muscle cell apoptosis in atherosclerotic plaques. J Thromb Haemost. 4, 664-670

21 Fleury, V. and Angles-Cano, E. (1991) Characterization of the binding of plasminogen to fibrin surfaces: the role of carboxy-terminal lysines. Biochemistry. 30, 7630-7638

22 Wiman, B. and Wallen, P. (1973) Activation of human plasminogen by an insoluble derivative of urokinase. Structural changes of plasminogen in the course of activation to plasmin and demonstration of a possible intermediate compound. Eur J Biochem. 36, 25-31

23 Shaw, G., Morse, S., Ararat, M. and Graham, F. L. (2002) Preferential transformation of human neuronal cells by human adenoviruses and the origin of HEK 293 cells. FASEB J. 16, 869-871

24 Ades, E. W., Candal, F. J., Swerlick, R. A., George, V. G., Summers, S., Bosse, D. C. and Lawley, T. J. (1992) HMEC-1: establishment of an immortalized human microvascular endothelial cell line. J Invest Dermatol. 99, 683-690

25 Gaussem, P., Grailhe, P. and Angles-Cano, E. (1993) Sodium dodecyl sulfate-induced dissociation of complexes between human tissue plasminogen activator and its specific inhibitor. J Biol Chem. 268, 12150-12155

26 Frisch, S. M., Vuori, K., Ruoslahti, E. and Chan-Hui, P. Y. (1996) Control of adhesiondependent cell survival by focal adhesion kinase. J Cell Biol. 134, 793-799

27 ffrench-Constant, C. and Colognato, H. (2004) Integrins: versatile integrators of extracellular signals. Trends Cell Biol. 14, 678-686

28 Ellis, V. and Murphy, G. (2001) Cellular strategies for proteolytic targeting during migration and invasion. FEBS Lett. 506, 1-5

29 Frisch, S. M. and Screaton, R. A. (2001) Anoikis mechanisms. Curr Opin Cell Biol. 13, 555-562

30 Talhouk, R. S., Bissell, M. J. and Werb, Z. (1992) Coordinated expression of extracellular matrix-degrading proteinases and their inhibitors regulates mammary epithelial function during involution. J Cell Biol. 118, 1271-1282

31 Mitra, S. K., Hanson, D. A. and Schlaepfer, D. D. (2005) Focal adhesion kinase: in command and control of cell motility. Nat Rev Mol Cell Biol. 6, 56-68

32 Kochtebane, N., Choqueux, C., Passefort, S., Nataf, P., Messika-Zeitoun, D., Bartagi, A., Michel, J. B., Angles-Cano, E. and Jacob, M. P. (2010) Plasmin induces apoptosis of aortic valyular myofibroblasts. J Pathol. 221, 37-48

33 Bess, J. W., Jr., Gorelick, R. J., Bosche, W. J., Henderson, L. E. and Arthur, L. O. (1997) Microvesicles are a source of contaminating cellular proteins found in purified HIV-1 preparations. Virology. 230, 134-144

34 Prokopi, M., Pula, G., Mayr, U., Devue, C., Gallagher, J., Xiao, Q., Boulanger, C. M., Westwood, N., Urbich, C., Willeit, J., Steiner, M., Breuss, J., Xu, Q., Kiechl, S. and Mayr, M. (2009) Proteomic analysis reveals presence of platelet microparticles in endothelial progenitor cell cultures. Blood. 114, 723-732 
35 Hajjar, K. A., Harpel, P. C., Jaffe, E. A. and Nachman, R. L. (1986) Binding of plasminogen to cultured human endothelial cells. J Biol Chem. 261, 11656-11662

36 Rouy, D. and Angles-Cano, E. (1990) The mechanism of activation of plasminogen at the fibrin surface by tissue-type plasminogen activator in a plasma milieu in vitro. Role of alpha 2-antiplasmin. Biochem J. 271, 51-57

37 Hoylaerts, M., Rijken, D. C., Lijnen, H. R. and Collen, D. (1982) Kinetics of the activation of plasminogen by human tissue plasminogen activator. Role of fibrin. J Biol Chem. 257, 2912-2919

38 Rossignol, P., Ho-Tin-Noe, B., Vranckx, R., Bouton, M. C., Meilhac, O., Lijnen, H. R., Guillin, M. C., Michel, J. B. and Angles-Cano, E. (2004) Protease nexin-1 inhibits plasminogen activation-induced apoptosis of adherent cells. J Biol Chem. 279, 1034610356

39 Horowitz, J. C., Rogers, D. S., Simon, R. H., Sisson, T. H. and Thannickal, V. J. (2008) Plasminogen activation induced pericellular fibronectin proteolysis promotes fibroblast apoptosis. Am J Respir Cell Mol Biol. 38, 78-87

40 Leskinen, M. J., Lindstedt, K. A., Wang, Y. and Kovanen, P. T. (2003) Mast cell chymase induces smooth muscle cell apoptosis by a mechanism involving fibronectin degradation and disruption of focal adhesions. Arterioscler Thromb Vasc Biol. 23, 238243

41 Zhang, X., Chaudhry, A. and Chintala, S. K. (2003) Inhibition of plasminogen activation protects against ganglion cell loss in a mouse model of retinal damage. Mol Vis. 9, 238-248

42 Reijerkerk, A., Mosnier, L. O., Kranenburg, O, Bouma, B. N., Carmeliet, P., Drixler, T., Meijers, J. C., Voest, E. E. and Gebbink, M. F. (2003) Amyloid endostatin induces endothelial cell detachment by stimulation of the plasminogen activation system. Mol Cancer Res. 1, 561-568

43 Tsirka, S. E., Rogove, A. D., Bugge, T. H., Degen, J. L. and Strickland, S. (1997) An extracellular proteolytic cascade promotes neuronal degeneration in the mouse hippocampus. J Neurosci. 17, 543-552

44 Chen, Z. L. and Strickland, S. (1997) Neuronal death in the hippocampus is promoted by plasmin-catalyzed degradation of laminin. Cell. 91, 917-925

45 Rossignol, P., Anglès-Cano, E. and Lijnen, H. R. (2006) Plasminogen activator inhibitor-1 impairs plasminogen activation-mediated vascular smooth muscle cell apoptosis. Thromb Haemost. 96, 665-670 


\section{FIGURE LEGENDS}

Figure 1. Identification of plasminogen activators and cellular activation of plasminogen. A. Fibrin-agarose zymography of CHO-K1, HEK-293 and HMEC-1 cells. The picture was taken after $24 \mathrm{~h}$ at $37^{\circ} \mathrm{C}$. The position of purified control references ( $100 \mathrm{pmol}$ of plasmin: $\mathrm{Pn}$, 1 pmol of tPA and 0.2 pmol of uPA) is indicated on the left. CHO-K1 and HEK-293 are shown to express active tPA whereas HMEC-1 express uPA, identified on the basis of their molecular mobility compared to references (Upper panel). Identity of the plasminogen activator was verified by inhibition of their proteolytic activity with specific antibodies $(\alpha)$ on radial diffusion fibrin-agarose gels (Lower panel). B Kinetics of plasmin formation. Progress curves of Glu-plasminogen $(0.125$ and $1 \mu \mathrm{M})$ activation by CHO-K1 cells. Plasmin formation was detected by measuring the release of $p$-nitroaniline $\left(\mathrm{A}_{405}\right)$ as a function of time. The effect of aprotinin $(2 \mu \mathrm{M})$ on plasmin activity is shown at $1 \mu \mathrm{M}$ plasminogen. Background activity in the absence of plasminogen was detected in presence $(2 \mu \mathrm{M})$ or absence of aprotinin. $\mathbf{C}$. Dose-dependent activation of plasminogen. CHO-K1, HEK-293 or HMEC-1 cells $\left(10^{5}\right.$ cells/well) were incubated with varying concentrations of Glu-plasminogen (0 to $2 \mu \mathrm{M})$ and $0.75 \mathrm{mM}$ CBS0065. Kinetics of plasmin formation $\left(\Delta \mathrm{A}_{405} / \mathrm{min}\right)$ was followed by measuring the release of $p$-nitroaniline. Data were fitted to the Michaelis-Menten equation. Non-specific activation $(\mathrm{k}[\mathrm{Pg}]$ in the equation) is proportional to plasminogen concentration. Data for specific plasminogen activation, obtained by subtracting the non-specific component from raw data, were plotted against the concentration of plasminogen $(\mathrm{Km}=\mathrm{Vmax} / 2 ; \mathrm{Km}=33 \mathrm{nM}$ for CHO-K1). The graph represents data for CHO-K1 cells. D. The specificity of plasminogen binding and activation was assessed using Glu-plasminogen supplemented, or not, with 50 $\mathrm{mM} \varepsilon$-ACA, or by pre-treatment of $\mathrm{CHO}-\mathrm{KI}$ cells with $50 \mu \mathrm{g} / \mathrm{mL}$ carboxypeptidase $\mathrm{B}$. Plasmin activity was completely abolished by $0.5 \mu \mathrm{M}$ aprotinin. Plasmin formation was measured using $0.75 \mathrm{mM}$ CBS0065. Results are expressed as $10^{3} \Delta \mathrm{A}_{405} /$ min (mean $\pm \mathrm{SEM}, \mathrm{n}$ $=3)$.

Figure 2. Early response of cells to plasmin formation: membrane blebbing and vesiculation

CHO-K1, HEK-293 and HMEC-1 cells were incubated with culture medium (CTRL) or with $1 \mu \mathrm{M}$ plasminogen $(\mathrm{Pg})$ and supernatants were collected after $24 \mathrm{~h}$ of incubation. Cell response to plasmin was identified by the multiple blebbing of the membrane and vesiculation. A. After isolation of these microparticles, their concentration was estimated by measuring the quantity of protein $\left(A_{280 \mathrm{~nm}}\right)$. B.C.D. The ultra structure of detached cells was observed by electron microscopy. Microparticles are released before any sign of cell death and have a size of around $300 \mathrm{~nm}$ as show at a higher magnification.

Figure 3. Western Blot of microparticles and cell lysate. A. HMEC-1 cells were incubated with $1 \mu \mathrm{M}$ plasminogen and supernatants were collected after $24 \mathrm{~h}$ of incubation. Microparticles were isolated as described in the Experimental section. Western blot analysis of uPA (A) and plasminogen (B) were performed using microparticle lysates. C. After incubation with culture medium (CTRL), $1 \mu \mathrm{M}$ plasmin (Pn) or $1 \mu \mathrm{M}$ active-site blocked plasmin $(\mathrm{Pn}-\mathrm{VFK})$, cell lysate and culture supernatant were analysed by Western blot using antibodies directed against laminin.

Figure 4. Advanced response to plasmin formation: detachment and cell death

Cells cultured in 96-well plates were incubated with $1 \mu \mathrm{M}$ plasminogen or culture medium for 0 or 72 h. A. Optic microscopy after $72 \mathrm{~h}$ of incubation in the absence (adherent cells, CTRL) or presence (detached, rounded cells) of $1 \mu \mathrm{M}$ plasminogen. B. Quantification of cell death is 
by MTT assay. After activation, detached cells were pulled-down by centrifugation and MTT was added. Bars represents the percentage of living cells (\%) as compare to control (without plasminogen), $\mathrm{n}=3 \pm$ SEM. C. DAPI and TUNEL staining of CHO-K1 cells after incubation (72 h) in the presence or absence of $1 \mu \mathrm{M}$ plasminogen. D. Quantification of TUNEL-positive CHO-K1 cells in response to plasminogen exposure for 0 to $72 \mathrm{~h}$. TUNEL index is expressed as the percentage of TUNEL-positive nuclei to DAPI-stained nuclei (bars represent mean \pm SEM, $\mathrm{n}=3)$.

Figure 5. Advanced response to plasmin formation: electron microscopy of apoptosis. Cells were incubated with plasminogen for 0 to $72 \mathrm{~h}$. A. Electron microscopy of control CHO-K1 cells. The normal typical characteristics of cells are detectable: normal nucleus $(\mathrm{N})$, nucleolus (NL) and cytoplasmic appearance including mitochondria (M) with mitochondrial crest, endoplasmic reticulum (RE) and intact membranes. B. After incubation for $48 \mathrm{~h}$ with 1 $\mu \mathrm{M}$ plasminogen, morphological features of early apoptosis were observed: change in nucleus (N) appearance with chromatin condensation into globular or crescent-shaped forms, and formation of lysis vesicles (LV). C. After incubation for $72 \mathrm{~h}$ with $1 \mu \mathrm{M}$ plasminogen morphological features of late apoptosis were observed: condensation of mitochondria and high chromatin condensation with compaction and fragmentation of the nucleus.

Figure 6. Plasmin-induced cell detachment upon proteolysis of the extracellular matrix. Cells were incubated with $1 \mu \mathrm{M}$ plasmin $(\mathrm{Pn})$ or active-site blocked plasmin (Pn-VFK). A. After $48 \mathrm{~h}$ of incubation the aminolytic activity of plasmin was assessed by addition of CBS0065. Results are expressed in $\mathrm{A}_{405} / \mathrm{min}$ (mean \pm SEM, $\mathrm{n}=3$ ). B. Quantification of cell death by MTT assay. After activation, detached cells were pulled-down by centrifugation and MTT was added. Bars represent the percentage of living cells (\%) as compare to control (without plasmin; mean \pm SEM, $\mathrm{n}=3$ )

Figure 7. A sequential procedure to analyze membrane blebbing, vesiculation and cell apoptosis

Near confluent adherent cells were incubated with plasminogen. The native tPA or uPA expressed by these cells allows detection of plasmin formation from $1 \mathrm{~h}$ of incubation. The plasmin formed at the surface of these cells induces time-dependent responses observed after cytospun and fixation of cells: (1) membrane blebbing and vesiculation, and (2) apoptosis. Culture supernatants were collected, cytospun and submitted to analysis as indicated in methods.

Table 1. From vesiculation to apoptosis

Summary of main data: plasminogen activator, Km, TUNEL index at $48 \mathrm{~h}(\%)$, viability at 48 $\mathrm{h}(\%)$ and vesiculation $\left(\mathrm{A}_{280}\right)$ of control $(\mathrm{CTRL})$ and plasminogen treated $(\mathrm{Pg})$ adherent cells. 
A

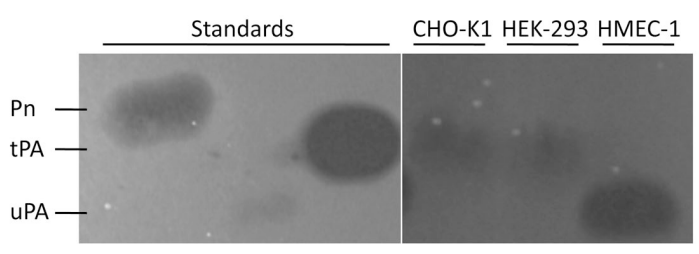

CHO-K1 HEK-293 HMEC-1

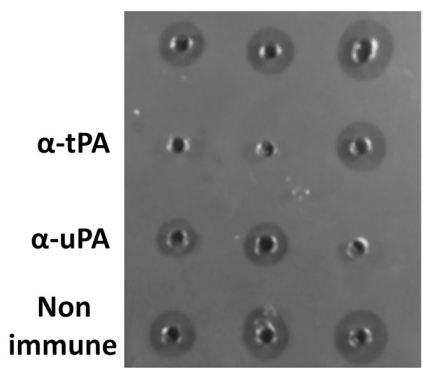

C

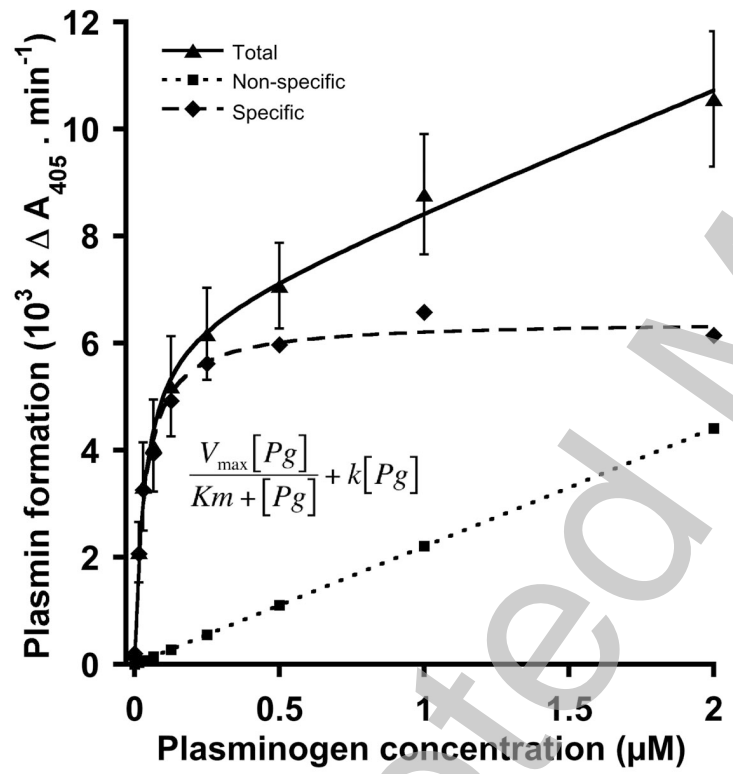

B

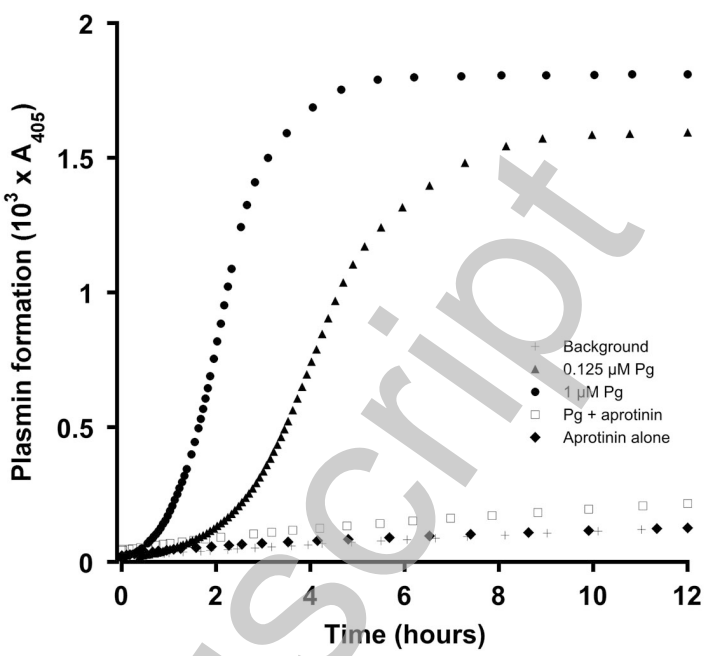

D

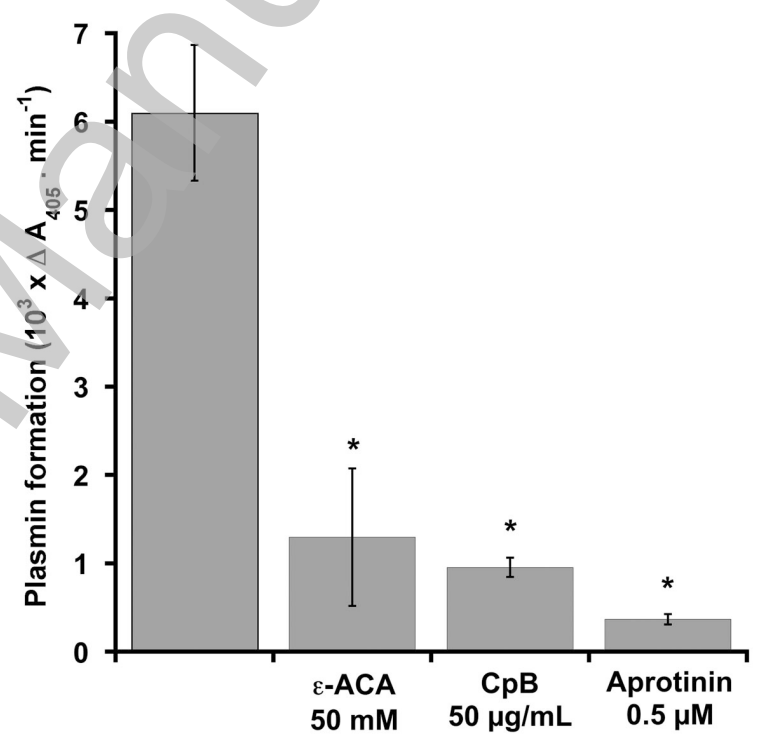

Figure 1 
A
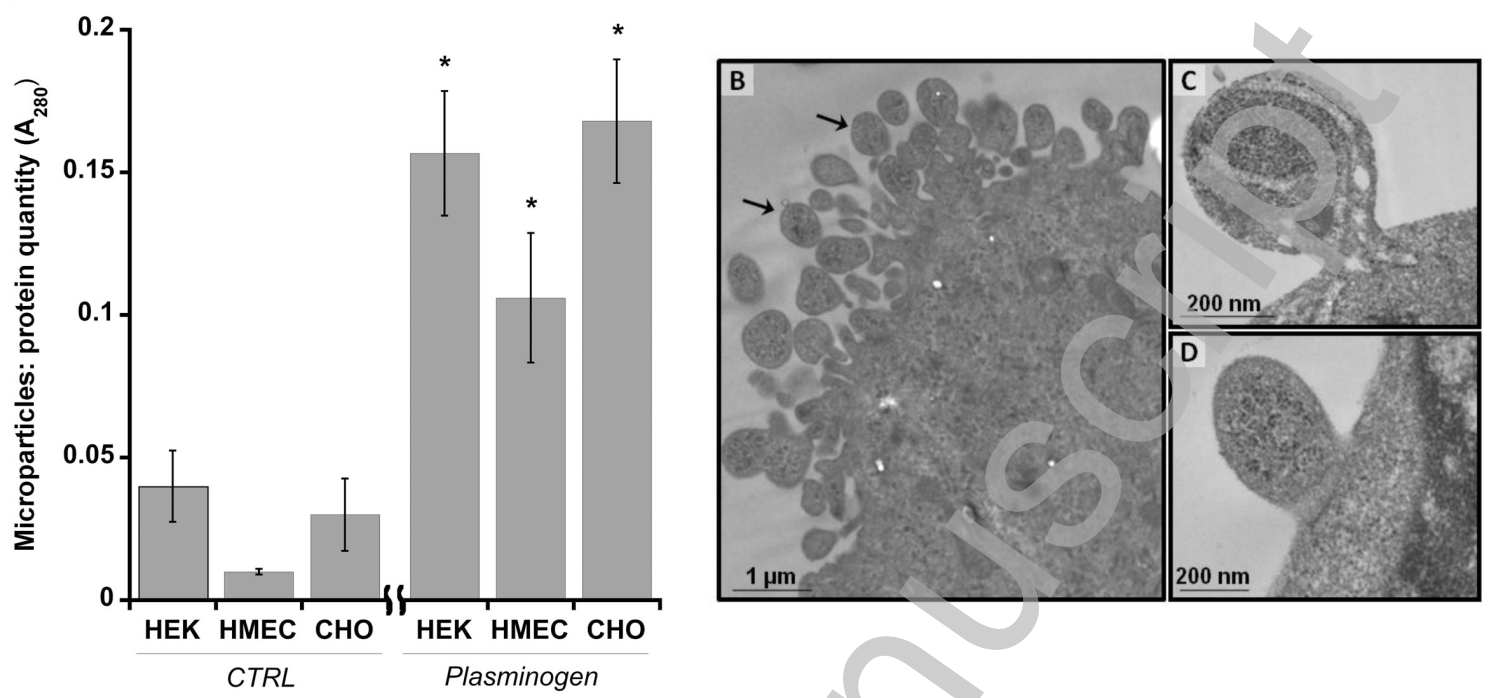

Figure 2 


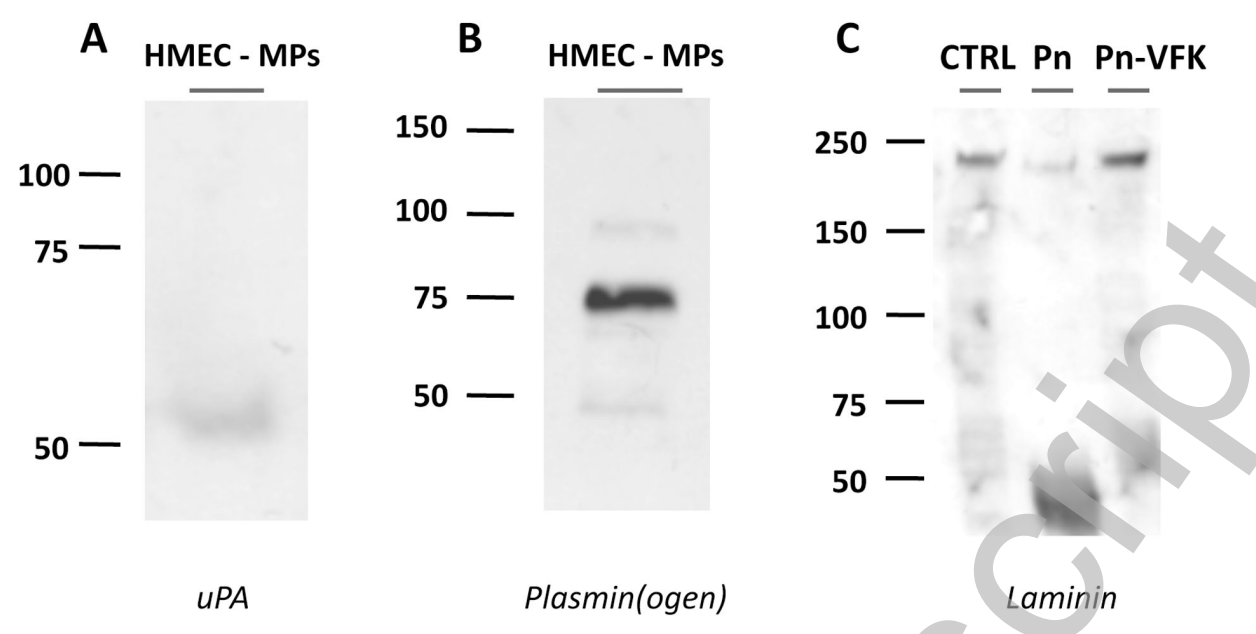

Figure 3

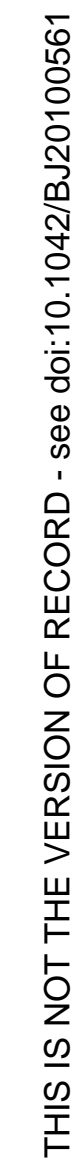


A

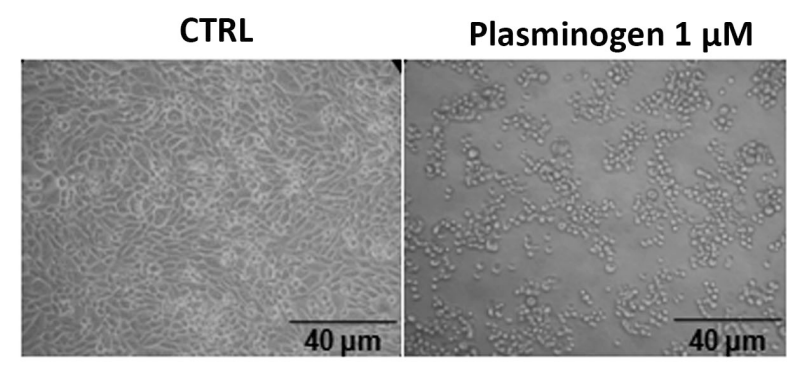

C

CTRL

Plasminogen $1 \mu \mathrm{M}$
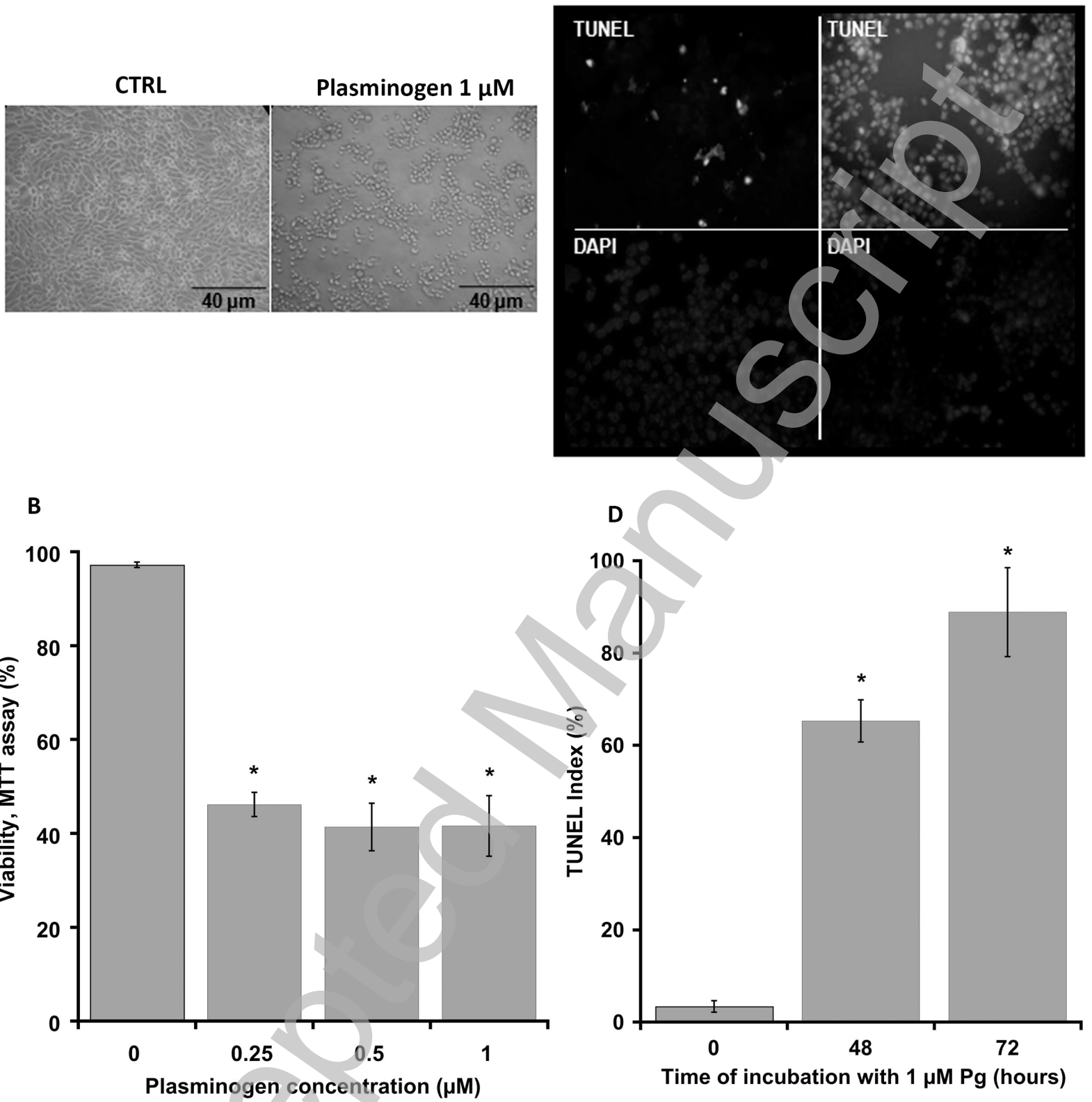

Figure 4 
A

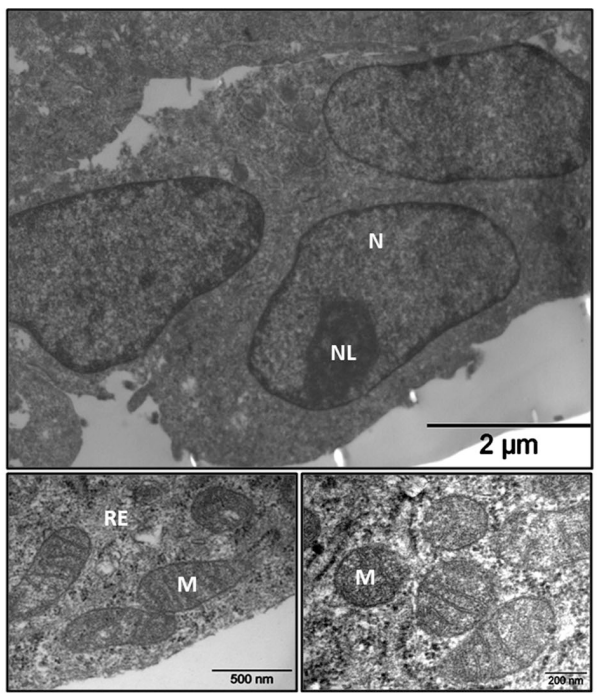

B

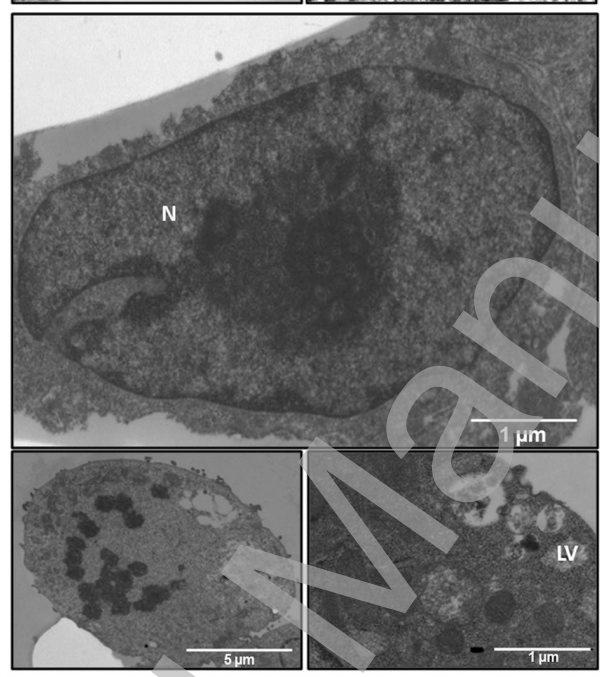

C

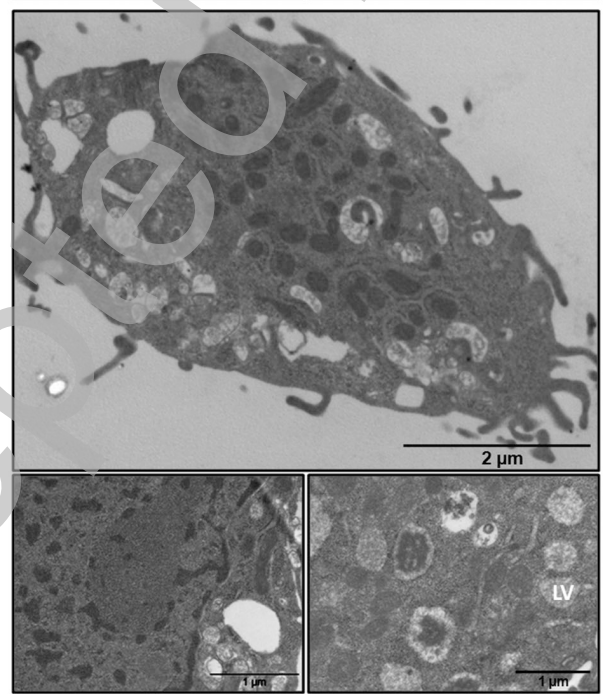

Figure 5 

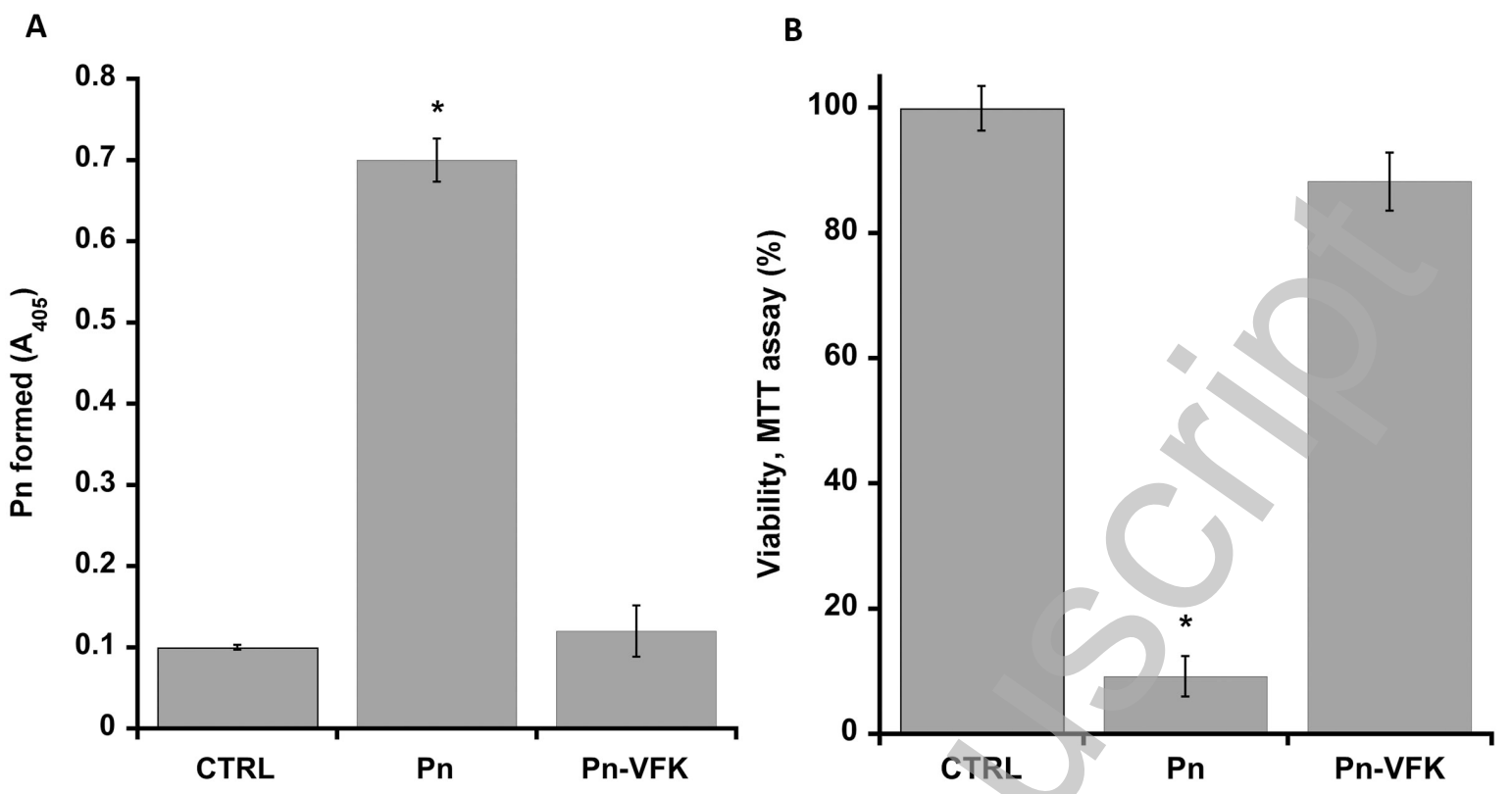

Figure 6 


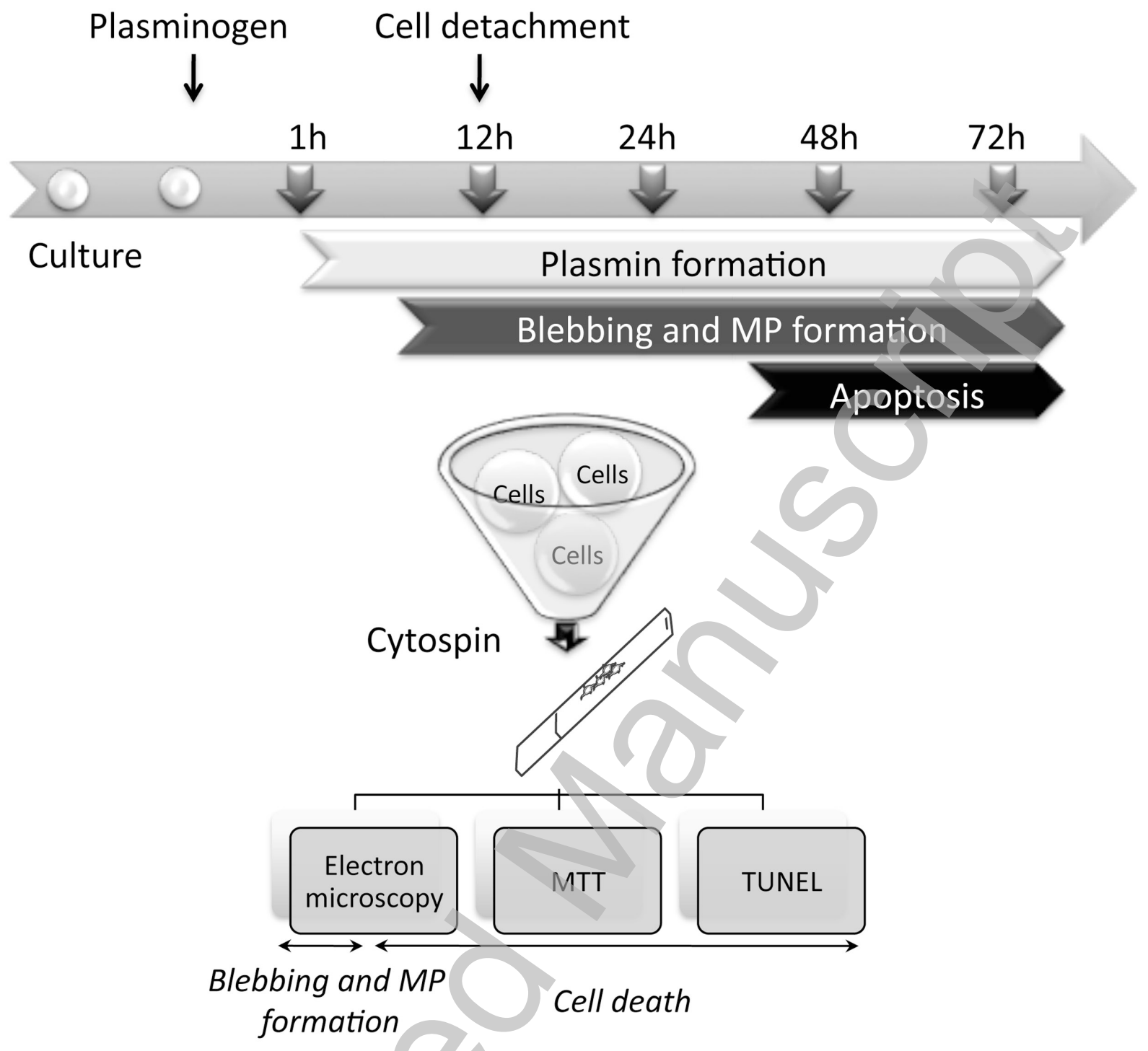

Figure 7 


\begin{tabular}{|c|c|c|c|c|c|c|}
\hline & & Activator & $\mathrm{Km}(\mathrm{nM})$ & $\begin{array}{l}\text { TUNEL index } \\
\text { at } 48 \mathrm{~h}(\%)\end{array}$ & $\begin{array}{c}\text { Viability at } 48 \mathrm{~h} \text {, } \\
\text { MTT assay (\%) }\end{array}$ & $\begin{array}{l}\text { Nanovesicles } \\
\text { (A } 280 \mathrm{~nm} \text { ) }\end{array}$ \\
\hline \multirow{2}{*}{ CHO-K1 } & CTRL & \multirow{2}{*}{ tPA } & - & 20 & 99 & 0.03 \\
\hline & $\mathrm{Pg}$ & & 33 & 63 & 42 & 0.168 \\
\hline \multirow{2}{*}{ HEK-293 } & CTRL & \multirow{2}{*}{ tPA } & - & 18 & 99 & 0.04 \\
\hline & $\mathrm{Pg}$ & & 31 & 45 & 54 & 0.157 \\
\hline \multirow{2}{*}{ HMEC-1 } & CTRL & \multirow{2}{*}{ uPA } & - & 13 & 99 & 0.01 \\
\hline & $\mathrm{Pg}$ & & 84 & 83 & 66 & 0.106 \\
\hline
\end{tabular}

\section{Table 1. From vesiculation to apoptosis}

Summary of main data: plasminogen activator, Km, TUNEL index at $48 \mathrm{~h}(\%)$, viability at 48 $\mathrm{h}(\%)$ and vesiculation $\left(\mathrm{A}_{280}\right)$ of control $(\mathrm{CTRL})$ and plasminogen treated $(\mathrm{Pg})$ adherent cells. 